\title{
HTLV-1-mediated dysregulation of the Wnt pathways: roles of Tax and HBZ
}

\author{
Guangyong Ma', Jun-ichiro Yasunaga ${ }^{1 *}$, Jun Fan', Shin-ichi Yanagawa², Masao Matsuoka \\ From 16th International Conference on Human Retroviruses: HTLV and Related Viruses \\ Montreal, Canada. 26-30 June 2013
}

Human T cell leukemia virus type 1 (HTLV-1) is the causative agent of adult T-cell leukemia (ATL). Dysregulations of cellular signaling pathways have been considered to be important strategies for HTLV-1 induced leukemogenesis. In this study, we found that a Wnt pathway-related protein, Dishevelled (Dvl)-associating protein with a high frequency of leucine residues (DAPLE), could be associated with Tax to activate the canonical Wnt signaling. However, in the downstream of the pathway, T-cell factor 1 (TCF1) and lymphoid enhancer-binding factor 1 (LEF1), which are two transcription factors mainly expressed in T-cells, could interact with Tax and suppress its transactivating ability. We further found virus production was greatly inhibited by TCF1/LEF1. Due to the high expression of TCF1/LEF1 in the thymus and their significant downregulation upon T-cell activation, we suspect TCF1/LEF1 may contribute to the HTLV-1 tropism on activated mature T-cells. On the other hand, HTLV-1 bZIP factor (HBZ) markedly suppressed canonical Wnt activation through targeting both TCF1 and LEF1. As a result, the canonical Wnt pathway was not activated in HTLV-1-infected cells, whereas the representative of noncanonical Wnt ligands, Wnt5a, which antagonizes canonical Wnt signaling, was overexpressed in HTLV-1 infected cells. Further experiments revealed HBZ could induce Wnt5a expression through activation of the TGF- $\beta$ pathway. Importantly, knocking down of Wnt5a in HTLV-1-infected cells repressed cellular proliferation and migration. By suppressing the canonical and enhancing the noncanonical Wnt pathway, HBZ is likely able to generate a favorable environment for HTLV-1 infection and persistence.

\footnotetext{
* Correspondence: jyasunag@virus.kyoto-u.ac.jp

${ }^{1}$ Laboratory of Virus Control, Institute for Virus Research, Kyoto University, Kyoto, Japan

Full list of author information is available at the end of the article
}

\section{Authors' details}

'Laboratory of Virus Control, Institute for Virus Research, Kyoto University, Kyoto, Japan. 'Laboratory of Gene Analysis, Institute for Virus Research, Kyoto University, Kyoto, Japan.

Published: 7 January 2014

doi:10.1186/1742-4690-11-S1-P91

Cite this article as: Ma et al:: HTLV-1-mediated dysregulation of the Wnt pathways: roles of Tax and HBZ. Retrovirology 2014 11(Suppl 1):P91.

Submit your next manuscript to BioMed Central and take full advantage of:

- Convenient online submission

- Thorough peer review

- No space constraints or color figure charges

- Immediate publication on acceptance

- Inclusion in PubMed, CAS, Scopus and Google Scholar

- Research which is freely available for redistribution

Submit your manuscript at www.biomedcentral.com/submit
C Biomed Central 